\title{
Social psychological factors and their relation to work-related stress as generating effect of burnout
}

\author{
Ricardo Prada-Ospina ${ }^{1}$
}

\begin{abstract}
${ }^{1}$ Doctor en Ciencias Empresariales. Doctor en Gestión. Magister en Administración. Profesor Titular, Facultad de Administración, Finanzas y Ciencias Económicas, Universidad EAN. Bogotá, Colombia. E-mail: rpradao@universidadean.edu.co
\end{abstract}

\section{Resumen}

El entorno cambiante actual donde las exigencias y la competencia al interior de las organizaciones genera altos niveles de presión, propicia la aparición de enfermedades profesionales: estrés, síndrome de burnout, entre otras, en las que el factor emocional o psicológico juega un papel determinante. El presente artículo está orientado a determinar la incidencia de cinco factores del trabajo y su repercusión en la motivación, el estrés laboral y el bienestar de los colaboradores de salud en cuatro hospitales de alta complejidad y otros de menor nivel en Medellín y Bogotá. Conforme a este objetivo se aplicó el cuestionario Maslach Burnout Inventory-MBI cuyas 22 preguntas se relacionaron mediante la agrupación en cinco factores del trabajo conducentes a producir agotamiento. La muestra estuvo formada por 360 profesionales de salud que respondieron al cuestionario MBI, adaptado a conocer su percepción con respecto a las variables Incentivos, Satisfacción y Burnout, entre otras.

Fueron encuestados profesionales de la salud de diversas disciplinas (médicos, anestesiólogos, enfermeras, auxiliares de enfermería, instrumentistas y administradores), en la búsqueda de indagar por los puntos débiles de su trabajo, la ausencia de incentivos, los niveles de desapego, así como la posible desmotivación inducida por ausencia de programas de bienestar. De los resultados obtenidos se pudo determinar que existen correlaciones entre las actividades laborales, el burnout y el desinterés emocional, la falta de incentivos, en relación con los programas de bienestar en el trabajo. Así mismo, los análisis de regresión evidencian el efecto negativo del síndrome de burnout y la incidencia negativa del estrés laboral en la motivación de los colaboradores.

Palabras clave: Motivación; Bienestar laboral; Estrés; Salud mental; Satisfacción laboral.

\section{Abstract}

Workers are the most valuable and important resource in organizations, however, the specific demands of high competitiveness due to globalization, market needs and rapid changes in organizations and companies have come to complicate the work environment in which their activities are developed. The importance of work is so strong that on several occasions the value of a person is defined by their profession or work, by their location in the formal structure of an organization or company, or by the titles and honors obtained (Pérez, 2005). This has led to daily work becoming more demanding every day and generates concern, suffering and illness in the human beings who work, affecting motivation, interest and professional satisfaction. As a result, it has diminished and the perception of efficiency is affected, until it achieves 
a form of detachment in the workplace (Maslach, \& Jackson, 1981).

A growing factor in recent times is the study and investigation of what happens to man in his work experience. The work environment is one of the main sources of risk of exhaustion or chronic work stress. This stress is related to pressure factors in the work environment, greater demands than the capabilities, resources and needs of the worker. Causes emotional fatigue, lack of personalization and low professional satisfaction, this can occur in occupations that are largely oriented in the field of providing assistance and services to people, in occupations where there is a relationship between the provider and the recipient of the service, caused by different situations, among them, the pressure for the increase of the productivity, the lack of training or conflicts not solved correctly. In turn, the persistence of stress related to work can lead to the development of burnout syndrome, which is characterized as a type of chronic work stress.

The purpose of this article is to determine the incidence of satisfaction and motivation in work-related stress and acceptance of wellbeing in the emergency rooms of four highly complex hospitals and two hospitals with lower levels of care, in Medellin and Bogotá by applying the Maslach Burnout Inventory-MBI whose 22 questions were related by grouping into five factors of work leading to exhaustion.

The research focuses on the analysis of five variables that were selected because of their importance for the involvement of workers and that will allow creating a specific concept of the elements that motivate and discourage workers in the health area using previously conducted studies. These are: stress related to work activities, burnout syndrome, work incentives and job satisfaction, and well-being at work.

The sample consisted of 360 health professionals who answered the MBI questionnaire, adapted to know their perception regarding the variables Incentives, Satisfaction and Burnout, among others. For this purpose, health professionals from different disciplines (doctors, anesthesiologists, nurses, nursing assistants, instrumentalists and administrators) were interviewed, in the search to investigate the weak points of their work, the absence of incentives, the levels of detachment, as well as the possible demotivation induced by absence of welfare programs.

From the results obtained it was possible to determine that there are correlations between work activities, burnout and emotional disinterest, the lack of incentives, in relation to workplace wellness programs. Likewise, regression analyzes show the negative effect of the burnout syndrome and the negative incidence of work stress on employee motivation.

Keywords: Motivation; Wellbeing at work; Stress; Mental health; Work satisfaction.

\section{Introduction}

Workers are the most important resource in the organizations, however, globalization, needs of the market and quick changes in the organizations and companies have complicated the working environment. Daily work is more demanding every day and it generates concern, suffering and disease in humans, affecting the motivation, satisfaction and professional fulfilment. As a result, it has decreased and the perception of efficiency is impaired, until it achieves a form of an attachment in the workplace (Maslach \& Jackson, 1981).

Stress is linked to factors of pressure in the working environment, greater demands than the capabilities, resources and needs of the worker. It causes emotional exhaustion, non-personalization and low professional fulfillment, this can take place in occupations which are oriented largely within the field of the provision of assistance and services to people, in occupations in which there is a rela- 
tionship between the provider and the recipient of the service, caused by different situations, among them, the pressure for increased productivity, lack of training or conflicts not resolved correctly. In turn, the persistence of work-related stress can lead to development of burnout syndrome, characterized as a type of chronic occupational stress.

This article aims to determine the incidence of the degree of satisfaction and motivation on work-related stress and acceptance of welfare in emergency rooms of four high complexity hospitals in Medellin and Bogota through the application of the Maslach adapted questionnaire.

\section{Theoretical framework}

The importance of the work is so strong that in several occasions the value of a person is defined by its profession or job, by its location in the formal structure of an organization or company, or by the obtained titles and honors (Pérez, 2005). An increasing factor in recent times is the study and investigation of which occurs to man in his labor experience. The work environment is one of the main sources of stress risk. The investigation focuses on the analysis in five variables that were selected by its importance to the affectation of workers and which will allow to create an own concept of the elements that motivate and discourage workers from the area of health using studies previously carried out. These are: Work-related stress, syndrome of burnout, motivation and satisfaction in the work, and wellbeing at work.

Work-related stress is a factor of risk for the psychological wellbeing of workers, consequently the organizations, worried by the increase of cardiovascular diseases, the high indices of obesity and the conditions associated to the activities performed in the work sites, currently pay more attention to this type of affectations of the health (Fernández-López et al., 2003). On the other hand, the syndrome of burnout, defined by García-Car- mona and Robles-Ortega (2011) as an inappropriate_answer to a chronic emotional stress, is the result of the above situations, causing in people a remarkable psychological and emotional exhaustion, physical tiredness, low enthusiasm and low personal fulfillment. In the area of health, this anomaly is frequent, because of the employees' high stress levels (European Agency for Safety and Health at Work, 2009). In Spain, for example, it has been found that nursery staff, especially female gender, endures higher work pressure in front $\mathrm{o}$ the daily situations of their job, causing anxiety, depression, headaches, high blood pressure, ulcers, among others (Limonero et al., 2004).

In the case of Colombia, the healthcare staffs live something similar. Work-related fatigue and dissatisfaction in employees of operating rooms is constant due to the stress that arises daily and the complexity of their activities, causing fatigue mainly by the extensive day, multiple activities in charge and not enough staff, perceiving also that compensation received falls short against the amount of work assigned. The quality of life of employees is affected by demand and the commitment that represent their functions, due to grueling work schedules and specially by the constant search for balance between personal - familiar life and working life, where most times the role as a healthcare professional wins.

\section{Work-related stress.}

Social, technological and cultural advances and specially the constant changes in the strategies of management of organizations carry both positive and negative consequences for the lifestyle of the workers. The permanent evolution and adaptation to changes of the market brings with it an accelerated growth in companies as well as a significant increase in the assigned activities to each partner; assuming in this way an excessive workload in 
comparison with their capabilities. Excess of work commitments and personal (externally and internally conditioned) associated with the lack of psychological resources of control or situational coping, leads to work-related stress (Dolan, García \& Díez, 2005). The term stress comes from physics and refers to the pressure exercised by one body on the other; the one who receives more pressure can be destroyed and was adopted by Psychology, becoming a denominator of the set of psycho physiologic symptoms such as: tiredness, loss of appetite, weight loss and asthenia, among others (Selye, 1950).

Work-related-stress could be perceived as those situations in which people feel threatened by their working environment, it takes place in their needs, personal and profession growth or in both physical and mental health, which affects the integration of the worker's field of work (França \& Rodríguez, 2005). Work-related-stress can be seen as "any force" that leads any psychological or physical factor beyond stability limits and it produces the individual tense behavior (Cooper, Cooper \& Eaker, 1988). According to Siegrist's (1996) point of view, work-related-stress is associated with the lack of equilibrium between effort and reward at work. There exists an optimum stress level for every person (Euestres). In a way that if it keeps an activating level above or below this level, it will have a negative effect over the working performance (Korman, 1974).

\section{Burnout syndrome.}

Work-related-stress concerns a considerable number of situations that belongs to daily-life and it is an excellent base for the development of the burnout approach, to which it is possible to get through a process of psychological accommodation between the stressed worker and the working job (Cherniss, 1980). The word "burnout" is an Anglo-Saxon word that means not only exhausted but also to lose motivation about work (Aranda, 2006). It is a level of occupational stress extended that includes emotional tiredness, interpersonal isolation and reduction of bonding with other people (Trigo, Teng \& Hallak, 2007).

Freudenberger (1974) is the author who introduces the concept of burnout. He defines it as the sensation of failure and as the exhausting existence resulting in overcharged energies, personal resources and spiritual strength in the worker. While, Pines and Kafry (1978) state that someone can undergo physical, emotional and behavioral fatigue. At that time, in 1976, the social psychologist Cristina Maslach studied the emotional responses of employees of helping professions to people, describing the gradual process of lack of responsibility and lack of interest among their workmates, with a term similar to that used by California attorneys. That is, burnout, which was a term of great social acceptance (Maslach \& Jackson, 1986). Unlikely, Gil-Monte and Peiró (1997) define burnout as the answer to chronic stress that is accompanied with a subjective experience of feelings, cognitions and attitudes that provoke physiologic changes in the person and negative consequences to working institutions. In the conceptual delimitation of the term two perspectives can be differentiated: the clinical and the psychosocial (Gil-Monte \& Peiró, 1997), being the clinic, that which has a state to which the subject comes as a result of work stress, supported proposal for the first contributions of Freudenberger (1974) and of Pines \& Aronson (1988). The psychosocial perspective is when this event is presented by the interaction of characteristics of the work environment and personal order, for which Maslach \& Jackson (1981), Gil-Monte, Peiró \& Valcárcel (1995), among others, contribute differences in different periods within their jobs.

Harrison (1999) considers the burnout hypothesis as the kind of stress that persists in working situations and turns out to be the constant and repetitive emotional pressure. It is associated to an intense and longterm implication with people. Farber (1983) 
explains that the relation of the burnout notion at work: "Burnout is a syndrome related to work. It emerges for the perception in the subject as a discrepancy between the realized efforts and what has been achieved" (p. 23).

Edelwich and Brodsky (1980) defines the burnout syndrome as the progressive loss of idealism, energy and the reasons lived by the people in the helping professions, as the result of the working conditions. This is an extended answer to chronic stressors that have an interpersonal and emotional basis (Grau-Alberola, Gil-Monte, García-Juesas \& Figueiredo-Ferraz, 2010), the nature of this is conceived by the physical, emotional and mental tiredness and it is caused by the person who has been involved for long periods of times, which affects him/her emotionally (Pines, Aronson \& Kafry, 1981). However, sometimes it is difficult to differentiate them, since their effects (pyscho-physiological and social) could be everlasting (Peiró \& Salvador, 1992). Barros and Nahas (2001) highlight the fatigue caused by the burnout's syndrome may lead to disrupt the individual's self. As a consequence of it, it favors the development of cold, negatives and insensitive personalities; it traduces the loss of humanity, hostility, intolerance and impersonal treatment. It arises from a malfunction among the individual's capacities and his/her requirements from work. This can be chronic, when the person cannot recover completely during work-time, or worse, considering then short-term situations (Martínez-Selva, 2004).

The establishment of high goals and the generation of expectations in the workplace are also latent causes of burnout syndrome, since people who manage to establish positive connections with their work seek to fulfill the proposed objectives and when faced with situations of failure or failure to comply with an expected result they become frustrated and end up developing this disorder (Marrau, 2009). This syndrome responds to a set of organizational factors such as the workplace climate, the institution's own culture and its concordance with individual values, interper- sonal relationships with peers, subordinates, bosses and clients, as well as the stimuli of the work environment for the fulfillment of assigned activities (Marrau, 2009).

The burnout syndrome is recognized as an occupational risk for professionals that understand health cares, education and personal services (Trigo et al., 2007). According to the European Agency for Safety and Health at Work (2009) it impacts in a higher degree to health and education professionals, who do activities that require big commitments such as guaranteeing healthy, safe and satisfied patient. Also, the semi-permanent care of children, pre-adolescents and adolescents. Young employees are prone to suffer from this disorder, taking into consideration that during their first working years these helpers are in a sensitization and adaption stage to the continuity of the service. There is a negative effect from work-related-stress in the family life of workers, due to physical and emotional tiredness, which is exteriorized in different scenarios such as home (Patlán, 2013).

In any case, there is still no consensus on equating the terms burnout and work stress, except for reconceiving some kind of similarity between the two concepts. However, definitions such as Freudenberger (1974), Maslach \& Jackson (1981) or Pines, Aronson \& Kafry (1981) reiterate in their works the difficulty in considering these terms as similar.

\section{Motivation.}

The term motivation is difficult to quantify and qualify among employees, because it is intimately linked to attitude and perception, even so it is defined as one of the principal influencers of success, learning and outcome. Consequently, human motivation must also be considered, it is defined as an emotional state that is generated in a person as a consequence of the influence exerted by certain motives on their behavior (Koenes, 1996).

Motivation comes from the Latin motivus (movement) and the suffix -ción (action and 
effect) which means: to move or generate energy that leads to the accomplishment of an aim; it also could mean have or offer motives for action. Motivation is what drives the individual to respond with different behaviors to particular activities or situations, therefore, work motivation is the force that encourages the worker to meet their own needs and achieve goals through the development of his job.

Labor motivation can be defined as the level of effort that people are willing to perform in their work (Boada, Tous, Ester \& Vigil, 1998; Boada, 1999; Boada, 2001). According to Koenes (1996) it is the emotional state of an individual derived from the influence exerted by certain motives. Aguado (2014) argues that motivation can affect the expected outcome and in turn reflects such behavior in the behavior, since it can be affected by external stimuli and personal factors, which affect the outcome and therefore the behavior that can occur in some situation. In short, it is what makes an individual act and behave in a certain way. It is a combination of intellectual, physiological and psychological processes that decides, in a given situation, how vigorously it acts and in which direction energy is channeled (Solana, 1993).

\section{Working satisfaction.}

A key factor in successful organizations is collaborators' satisfaction in their daily tasks inside companies, which make efforts by doing some satisfaction studies and evaluating each of the factors that may influence on decision making and the quality of the offered services. Different researchers have contributed by pointing out some definitions on work satisfaction, which provides the well-being study at work and allows the beginning of interaction analysis in the workers' environment.

Labor satisfaction is revealed as a predictor of permanence at work and of labor productivity, besides being an indicator of psychological well-being (Mañas, Salvador, Boada,
González \& Agulló, 2007). Meliá \&d Peiró (1989) define work satisfaction as an attitude or ensemble of developed attitudes by people to their employment situation. Also it can be related to work in general or some specific facets while Koontz \& O'Donell (2006) state that work satisfaction has to do with the wellbeing experienced at work, when a desire is fulfilled, to which work motivation is associated.

\section{Work well-being.}

Work well-being is a set of characteristics that include positive personal experiences in the development of their work, which generate the worker, a high degree of satisfaction; generating a high index of well-being both physical, mental and social; understanding that labor well-being does not distinguish occupations or ranks within the company (Rodríguez $\&$ Reyes, 2010). Interest in the study of wellbeing has existed for some years now. Research on this aspect, have broadly pointed out, that there are psychological factors that favor the increase of well-being. In this respect, Blanch, Sahún, Cantera \& Cervantes (2010) refer that the most commonly accepted concept of wellbeing (subjective or psychological) lies in a set of value judgments, as well as emotional reactions regarding the level of satisfaction, positivism and satisfaction, obtained in the experiences of life, which makes think that an optimistic and pleasant view of the individual in front of their own and environmental conditions will depend on the degree of well-being perceived and achieved by it.

One of the critical factors to ensure the well-being of workers is the opportunity for workers to develop their skills and knowledge in the organization, making their contributions generates new ideas that are taken into account within the operation and / or strategy of the organization. The development of leaders and follower groups is of vital importance for the development of workers in the company, as is economic remuneration, although this does 
not guarantee the happiness of the workers nor their conformity with their long-term life (Nader \& Solano, 2010).

Regarding health institutions, different studies on the welfare of the work have been carried out. For example, in Spain a study was carried out on elements that affect the wellbeing of emergency physicians; finding that the lack of resources to develop their work, burnout syndrome, vigor, exhaustion and dedication are crucial elements when talking about well-being. The highest scores occur in exhaustion and dedication, and lack of time for rest as a trigger for motivation lack of vigor and commitment (Castaño et al., 2011).

\section{Research methodology}

The research is type descriptive and has a quantitative nature. This kind of research is observable, measurable and copied since in its elaboration, it must collect and analyze quantitative data. Besides, it uses some language with math precision and employs some statistic models on the related variable in order to study its phenomena and establish probabilistic hypothesis, that in case they are accepted and demonstrated, they can be done as general theories.

\section{Participants and procedure.}

The research was carried out in four hospitals of high complexity in the care of patients and 3 of lower levels, located in Bogotá and Medellin that agreed to respond to the Maslach Burnout Inventory questionnaire, adapted to this research. A total of 360 health professionals (183 doctors, 133 nurses, 65 instrumentalists and 15 administrative staff) received the surveys. In the end, 24 answered surveys were rejected.

It was decided to use the Maslach questionnaire because it is one of the most widely used instruments in the world today. For the knowledge of the burnout syndrome three aspects are used: 1) emotional exhaustion,
2) depersonalization and 3) reduced personal fulfillment (Maslach \& Jackson, 1996; Maslach, 1979, Maslasch \& Leiter, 1999). According to Maslach \& Jackson (1996), a sector that is very vulnerable to suffer this malaise are mainly doctors, and between $20 \%$ and $35 \%$ nurses because the levels of burnout between both sectors are of the highest averages, because it has important effects on the performance of their work, generates labor conflicts and mental instability that could lead them to suicide. The MBI model seeks to evaluate a more varied range of emotions and thoughts resulting from work practice; This instrument is considered the most used and measures: emotional exhaustion (AE) depersonalization (D) and personal fulfillment (RP) where once applied and obtained the results, we can speak of professionals with burnout, when the first two dimensions, $\mathrm{AE}$ and $\mathrm{D}$ are high scores, while the (RP) dimension is at a lower level (Maslach \& Jackson, 1986).

This scale has a high internal consistency and reliability close to $90 \%$ and consists of 22 items in the form of affirmations, on the feelings and attitudes of the professional in their work and towards patients and their function is to measure professional burnout.

\section{Factors of work}

According to Jones (1980), labor factors influence the emergence of Burnout syndrome in health personnel, differentiating various groups of causes. Within these causes, we can first mention the work overload as a cause of burnout, which is mainly related to the emotional exhaustion dimension. In this sense, the work overload resulting from the activities related to the work of health personnel is considered an important psychosocial risk factor, possibly due to the increase in the population that attends for medical attention and the strong assistance pressure to reduce the lists Standby. Consequently, there is a lack of time for the development of clinical activities, which affects health professionals. 
Another aspect to consider is the one related to incentives, that is, the rewards that the health professional receives in accordance with the work performed. They include social recognition, financial rewards (salary) and intrinsic rewards. Even when the salary is not the most important to motivate the health professional, however, a low salary can have a negative impact on the level of responsibility of these professionals.

The satisfaction for the work done, that is, the acknowledgment of the work by the management, the work colleagues, the patients and he, is related to the burnout. Professionals who find their work little recognized by bosses and patients or with an inadequate intrinsic motivation, that is, when there is a low degree of identification with the workplace are equally affected. Also important are the relationships of camaraderie based on teamwork, because with the help of others the professional faces better the demands of work.

Another labor cause that generates burnout is the absence of welfare programs or social support programs. This social support refers to the framework of social relationships that complement personal resources for the development of adaptive coping in situations of need, and includes informal ties, friends and family, as well as formal links, bosses / supervisors and peers job. It is important that health professionals perceive the existence of impartiality in their place of work. Thus, some correlation could be observed between the five proposed dimensions of burnout syndrome, so that it has repercussions on the development of this syndrome in its employees.

\section{Adaptation of the MBI questionnaire.}

The objective of the use of the instrument was to obtain and consolidate the opinions of the professional staff in emergency room health of the four institutions about their perception of the incidence of the degree of satisfaction and motivation on the work stress that they manage and the acceptance of programs of welfare in institutions.

Taking into account the aforementioned factors of work, as elements that influence the onset of stress, the 22 questions of the MBI questionnaire are used to evaluate the five variables object of the study, which were interrelated as follows: to evaluate the dimension Activities that in Similar form measures the emotional fatigue and physical exertion of the staff, questions 4, 5, 10, 22 were grouped, expecting a maximum score of 36 . To measure the variable Burnout, which measures the degree of exhaustion, questions 1, 3 were grouped , 8, 14, 16, 20, for a maximum expected score of 30 points. To evaluate the variable Incentives, questions 7, 9, 15, and 18 were used for a total of 20 maximum points. For the Welfare variable, we worked with questions 2, 6, 11 and 13 and, finally, for the Satisfaction dimension, questions $12,17,19$, 21 were taken into account, with a maximum expected score of 20 . The levels of intensity were adapted using a Likert scale with the following values and meanings: (0) never (1) few times (2) once a month or less (3) a few times a month or less (4) once per week (5) a few times a week (6) every day.

The questionnaires MBI were delivered in a personalized way in the institutions, at working hours and in the staff place of work. The period of the work filed was during the first four months of 2017. The obtained score has been studied statistically with the SPSS program, the 22 version that allows identifying the relationship among the target variables.

\section{Data analysis and final results}

This epigraph offers some analysis of the information obtained from doctors and nurses based on the activities they do. This analysis is carried out in two parts: the first one makes an univariate descriptive analysis that permits to observe specialists behavior according to their characteristics. The second part realizes an inferential analysis that is directed to observe the influence of a variable over the rest. 


\section{Descriptive analysis.}

The descriptive analysis has a basis a unidimensional analysis so that it is possible to outlook the collected data. It was found that $63 \%$ of the interviewed in a sociodemographic scale are women (91 doctors, 89 nurses, 38 instrumentalists and 9 administrators), and $37 \%$ of the respondents were male (56 doctors, 44 nurses, 27 instrumentalists and 6 office staff). As for participants' ages in the study, it could be determined that the average corresponds to people who are 26 and 45 years old, with a slight percentage of people being older than 45. In the chart 1 , it is shown the average statistic result of all four overviews.

Table 1. Statistic outcome of percentages.

\begin{tabular}{|c|c|c|c|c|c|c|c|c|}
\hline \multirow{2}{*}{ Dimension } & \multirow{2}{*}{ Average } & \multirow{2}{*}{$\begin{array}{c}\text { Standard } \\
\text { Deviation }\end{array}$} & \multirow{2}{*}{ IQR } & \multicolumn{5}{|c|}{ Percentiles } \\
\hline & & & & $0 \%$ & $25 \%$ & $50 \%$ & $75 \%$ & $100 \%$ \\
\hline Activities & 3.32 & .78 & .89 & 1.11 & 2.89 & 3.5 & 3.78 & 5 \\
\hline Burnout & 3.45 & .63 & .75 & 1.25 & 3 & 3.5 & 3.75 & 4.75 \\
\hline Incentives & 3.61 & .78 & 1.21 & 1.17 & 3 & 3.67 & 4.21 & 5 \\
\hline Well-being & 3.44 & .68 & .93 & 1.73 & 3 & 3.57 & 3.93 & 4.53 \\
\hline Satisfaction & 3.65 & .74 & .81 & 1.75 & 3.25 & 3.75 & 4.06 & 5 \\
\hline
\end{tabular}

It is possible to see a median tendency that is very similar in the five dimensions. The less perspective is found in Well-being activities. Nonetheless, it is one that scatters values the most; this explains that there are individuals that present a high and low participation in well-being activities. On the other hand, satisfaction outcomes the highest median participation, the average person with less qualification in this dimension is near to the two units, providing a high valuation to satisfaction.

For participation in activities and the perception of stress there is more individuals that register an average from 2 to 3 that results from 4 to 5 , while the perception of incentives, motivation and behavioral programs highlight opposite results. This reveals a low tendency to participation in activities, as well as low stress scores.

To complement the description, it should be calculated the participation of every variable on the total of the dimension in order to test what of them have the highest participation. The next graphics show the percentage in the variable participation per each dimension.

It is perceptible that the participation in activities has been influenced by the qualification in high numbers in work-motivation, followed by a high perception in the incidence in the timetable of those activities. Besides, numbers with low response, as an average in participation, is the incidence of additional costs that these activities produce.

Regarding the incentives, the participation of some numbers is somehow similar. However, highest perceptions are reported in the incentives offered by personal institutions, which influence in their work-motivation and performance, whereas the lowest scores are reported in the achievement of proposed goals, they represent a higher encouragement. As for motivation, the highest scores report that when institutions demonstrate the importance of their work in the institutions. In relation to stress, the highest reports are showed when the nature of the activities have provoked stress moments, while the lowest report is stated when professionals invest some time in their health, improving the performance at work but affecting family and themselves.

\section{Inferential analysis.}

In order to evaluate the relation of the dimensions in the questionnaires, it has been adjusted a regression model on the middle stress level and other regressive variables. It will be illustrated the associations between interest variables. 
Graphic 1. Results of dispersion.

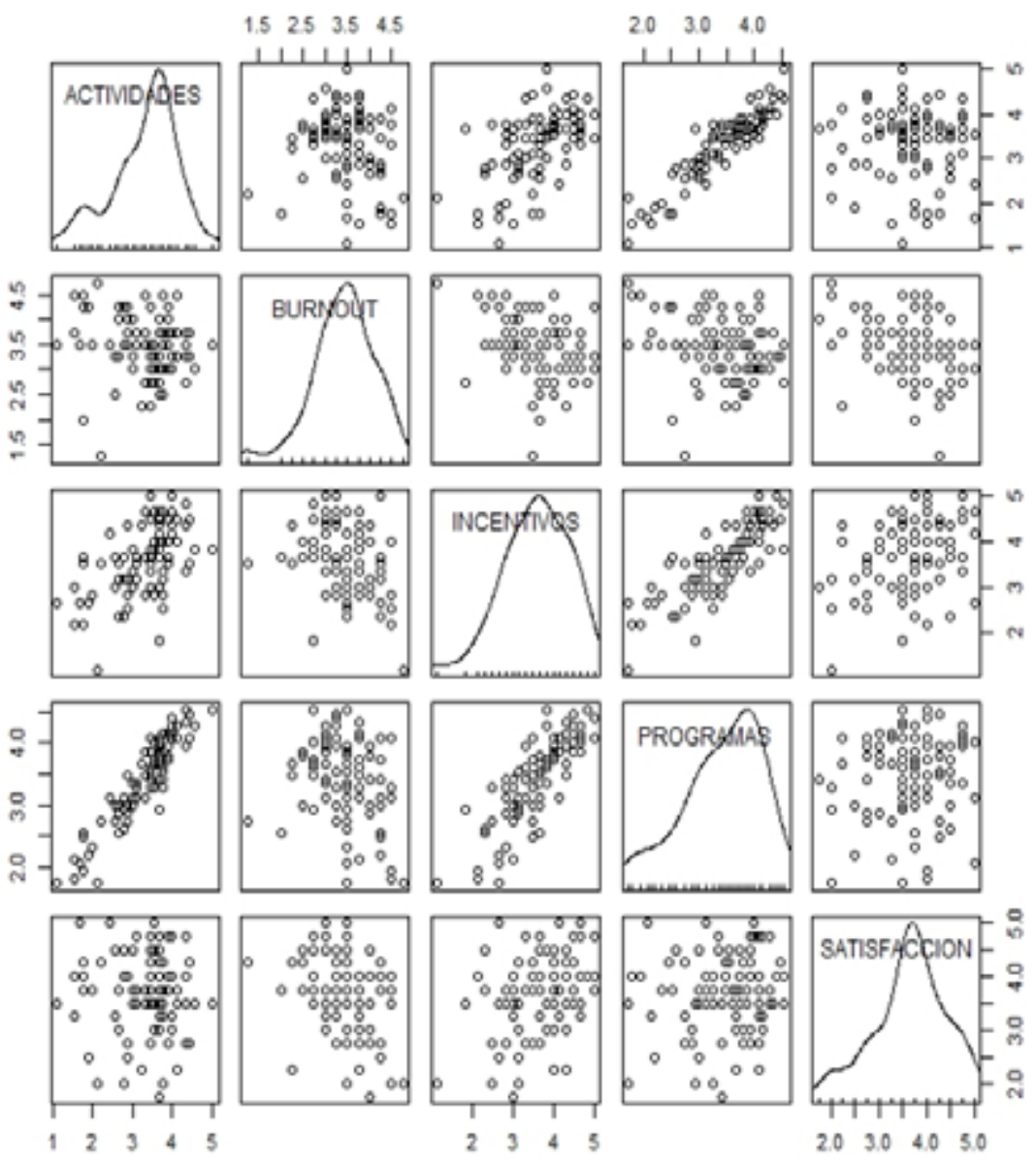

Graphic 1 exposes the results in both dispersion and distribution of each variable. This allows evaluating the relation between variables or dispersion. It is can be observed a direct relation among well-being activities, motivation and some others between satisfaction and incentives. On the other hand, it is visible some kind of inversed trend between stress and a number of activities, between satisfaction and stress and between stress.
Pearson correlations are bivariate in the dimensions presented in the chart 2. Using Holm's adjustment, they can be determined (in color) the significant correlations in $95 \%$. It can be observed that it exists some negative correlation between every dimension against stress, which implies the more one of the rises, the more stress diminishes. On the other hand, it is noticeable that there are inversed significant relations with incentives and satisfaction. In other cases relations are positive.

Table 2. Coefficient in Pearson's correlation.

\begin{tabular}{cccccc}
\hline & Activities & Burnout & Incentives & Well-being & Satisfaction \\
\hline Activities & 1 & -.1237 & .5219 & .9217 & -.0314 \\
Burnout & -.1237 & 1 & -.3455 & -.2418 & -.3258 \\
Incentives & .5219 & -.3455 & 1 & .812 & .3153 \\
Well-being & .9217 & -.2418 & .812 & 1 & .1219 \\
Satisfaction & -.0314 & -.3258 & .3153 & .1219 & 1 \\
\hline
\end{tabular}


The regression model is adjusted to permit evaluating the influence model of activities participation, incentives, programs and satis- faction under the following model:

Stress $=$ alpha + activities + Incentives + programs + satisfaction $+\varepsilon$, with $\varepsilon \sim N(0, \sigma)$

Table 3. Statistical abstract of the regression model.

\begin{tabular}{ccccc}
\hline & Estimation & Standar Error & T. number & p. number \\
\hline Intersection & 4.965 & .424 & 11.721 & $<2 \mathrm{e}-16$ \\
Activities & .011 & .097 & .114 & .91 \\
Incentives & -.225 & .102 & -2.197 & .031 \\
Satisfaction & -.203 & .092 & -2.206 & .03 \\
\hline
\end{tabular}

Using Step way method to choose the best model, with the BIC criteria, it must be included the incentive and satisfaction variables, obtaining the next adjustment:

Table 4. Adjustment to the regression model.

\begin{tabular}{ccccc}
\hline & Estimation & Standar Error & T. number & p. number \\
\hline Intersection & 4.965 & .424 & 11.721 & $<2 \mathrm{e}-16$ \\
Activities & .011 & .097 & 0.114 & .91 \\
Incentives & -.225 & .102 & -2.197 & .031 \\
Satisfaction & -.203 & .092 & -2.206 & .03 \\
\hline
\end{tabular}

According to the model, it is observed that for each unit that increases in incentives, stress decreases in 0.218 units. Similarly, for each unit that increases satisfaction, it is obtained a reduction of 0.205 units of stress.
The model contemplates a $\mathrm{R}^{2}$ close to 0.2 . Also, we can see that $\mathrm{p}$. numbers are lower than 0.05 , which implies the rejection of the hypothesis that zero is the coefficient of the variable. 
Graphic 2. Adjustment diagnosis. Burnout approximation to incentives + satisfaction.
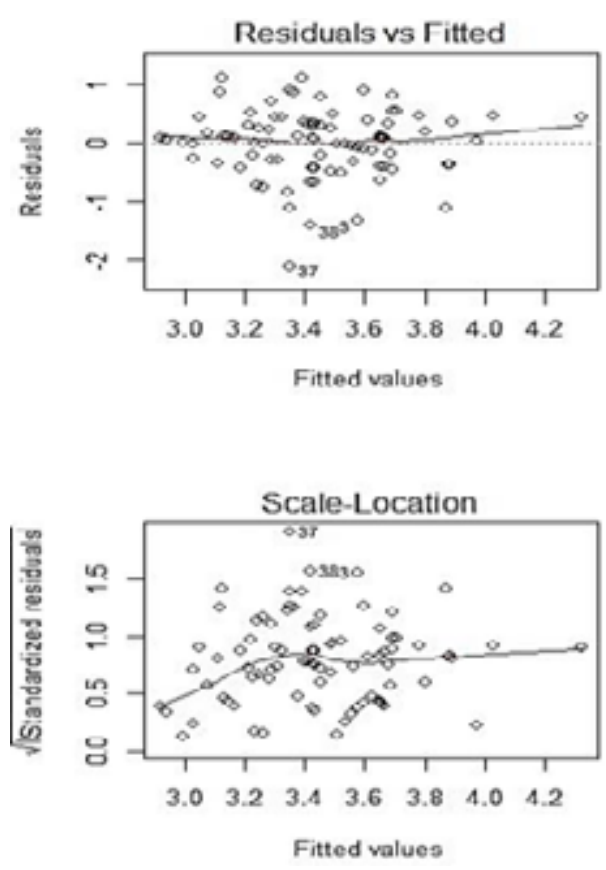

Graphic 2 shows the basic adjustment diagnosis, the tendency is normal with presence of two extreme data. The residence tend to have a zero median, there are two points in which its adjustment against the residual is considerably high.

\section{Conclusions}

When the employee lives in a complex and hostile environment, not only he is affected in his satisfaction level but also in the materialization of his personal and professional needs. This also leads to an impact on their physical and mental health triggering work stress. Extreme chronic and continuous stress situations will cause the burnout syndrome.

Stress symptoms are not presented immediately or dominant. A series of complex reactions in a biologic, psychologic and social in circumstances of pressure and internal struggle in which the resources of each worker can be exhausted until exhausted determines the stress. If this perturbation persists, it will get a critic situation in which the resistance is over and it will appear physical and psychologic tiredness.
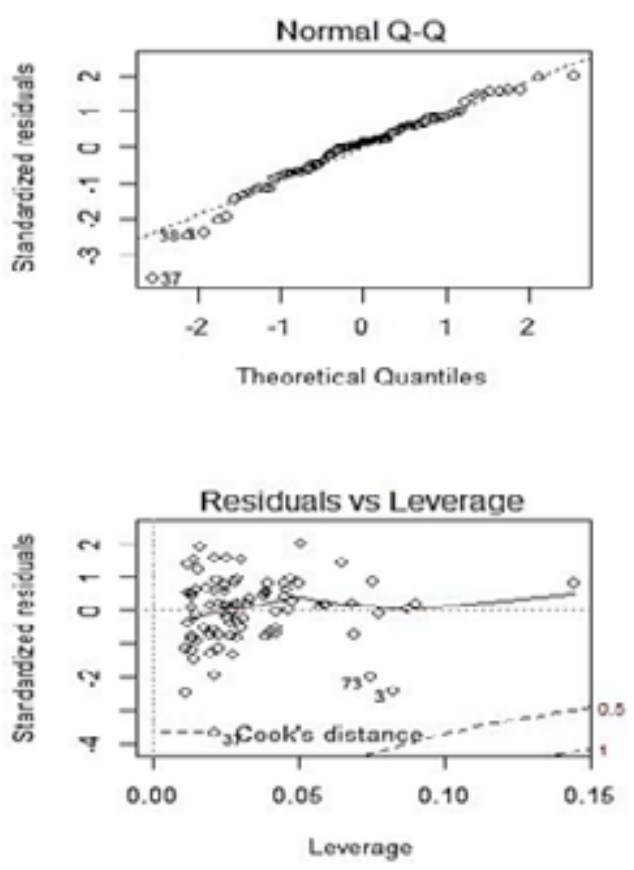

According to obtained results, the higher stress level the lower motivation for employees, while the more and the better well-being programs, it could be evident that they have a positive impact in co-workers' motivation. Therefore, the hypothesis is confirmed to be true.

It is important to mention that among the variables of the well-being program and the burnout syndrome, the correlation is significantly low in comparison to the first analyzed, which translates a weak incidence.

The burnout syndrome variable and the work satisfaction variable have such a negative correlation, which is evident for those institutions case of study, especially people working in emergency rooms, stress is a factor that affects in a disproportional and inversely way in work satisfaction. That is, the higher the stress level the lower the motivation.

There is no significant trend between Wellbeing activities and Work Satisfaction, and their correlation number. Despite of having a negative behavior, this evinces a weak relation among these dimensions, an additional data to confirm that there is not such relation among the variables exposed as study. 
The objective of this study was to explain the role of psychological and social factors in the burnout process, with special consideration to the role played by the effect of work activities and their incentives on the level of satisfaction and burnout. The findings of the present study suggest a relationship between work factors as psycho-social predecessors and the development of burnout. In addition, we found that the well-implemented welfare program moderates the relationship such that those who experience social support exhibit a reduced influence of social comparison in their subsequent burnout.

This document makes a number of important contributions. First, it offers a wellfounded theoretical framework that contributes to the understanding of the burnout experience. Based on a correlational exercise of the notions of labor affectation, it does not intend to replace the current models of the burnout process, but rather tries to complement it by enhancing the working context of the burnout. In that sense, it establishes an agenda for this potentially important current of research on burnout. Second, the article can help predict burnout in a generalized sample from other disciplines, different from health.

\section{References}

Aguado, L. (2014). Emotion, affection and motivation. Madrid: Alianza Editorial.

Andrews, F.M., \& Withey, S.B. (1976). Social indicators of well-being: America's perception of life quality. New York: Plenum. doi: 10.1007/978-1-4684-2253-5_3

Aranda, C. (2006). Reliability and validation of the scale Maslach Burnout Inventory (Hss) in workers in western México. Salud Uninorte, 32(2), 218-227. doi: 10.14482/sun.32.2.8828

Barros, G.V. \& Nahas, V.M. (2001). Comportamento de risco, auto-avaliação do nível de saúde e percepção de estresse entre trabalhadores na industria. Revista Saúde Pública, 35(6), 554-570. doi: 10.1590/s003489102001000600009
Blanch, J., Sahún, M., Cantera L \& Cervantes G. (2010). General Labor Welfare Questionnaire: Psychometric Structure and Properties. Revista de Psicología del Trabajo y de las Organizaciones, 26(2), 157-170. doi: 10.5093/ tr2010v26n2a7

Boada, J. (1999). Psychology of (Work + Organizations + Human Resources). Barcelona: PPU.

Boada, J. (2001). Human Capital: 52 Casos Prácticos. Barcelona: Granica.

Boada, J., Tous, J., Ester, S. y Vigil, A. (1998). Predictive study on internal motivation in Social Services professionals and non-university professors. In R. de Diego \& J.D. Valdivieso (Coords.). Psicología del Trabajo (pp. 141-158). Madrid: Pirámide.

Castaño, M., Gelabert, M., Cantero, M.C., Quiles, M.J., y Perona, V. (2011). Analysis of some elements of work welfare in the medical services of hospital emergency services. Between illusion and exhaustion. Ansiedad $y$ Estrés, 17(2/3), 221-231.

Cooper, C., Cooper, R. y Eaker, L. (1988). Living with stress. Londres: Penguin Books.

Cherniss, C. (1980). Professional burnout in human service organizations. Nueva York: Praeger.

Dolan, S., García, S. \& Díez, M. (2005). Self-esteem, stress and work. España: McGraw Hill.

Edelwich, J. y Brodsky, A. (1980). Stages of disillusionment in the helping professions. Nueva York: Human Sciences Press.

European Agency for Safety and Health at Work European Risk Observatory Report (EU-OSHA). (2009). OSH in figures: stress at work - facts and figures. European Agency for Safety and Health at Work. Luxembourg: Office for Official Publications of the European Communities

Farber, B.A. (1983). Stress and burnout in the Human Service Professions. New York: Pergamon Press.

Fernández-López, J.A., Siegrist, J., Rödelb A. y Hernández-Mejía, R. (2003). Work stress: a new risk factor. What do we know and what can we do? Atención Primaria, 31(8), 000-0 doi: $10.1157 / 13047737$ 
França, A.C.L y Rodríguez, L.A. (2005). Stress e trabalho: uma abordagem psicossomática. São Paulo, Atlas

Freudenberger, H. (1974). Staff burnout. Journal of Social Issues, 30, 159-165. doi: 10.1111/ j.1540-4560.1974.tb00706.x

García-Carmona, R. y Robles-Ortega, H. (2011). Resistant personality and sense of coherence as predictors of Burnout in health care personnel in intensive care. Ansiedad y Estrés, 17(2/3), 99-112.

Gil-Monte, P.R. y Peiró, J.M. (1997). Psychic work-at-work: the burning syndrome. Madrid, España: Editorial Síntesis.

Gil-Monte, P.R., Peiró, J.M. y Valcárcel, P. (1995). A causal model of burnout process development: An alternative to Golembiewski and Leiter Models. Paper presented at the VII European Congress on Labor and Organizational Psychology. Gyor, Hungría.

Grau-Alberola, E., Gil-Monte, P.R., García-Juesas. J.A., y Figueiredo-Ferraz, H. (2010). Incidence of burnout in Spanish nursing professionals: A longitudinal study. International Journal of Nursing Studies, 47, 1013-1020. doi: 10.1016/j. ijnurstu.2009.12.022

Harrison, B.J. (1999). Are you to burn out? Fund Raising Management, 30(3), 25-28.

Jones, J.W. (1980). Staff Burnout Scale for Health Professionals (SBS-HP). Park Ridge, Illinois: London House.

Koenes, A. (1996). Staff management and motivation. España: Ediciones Díaz de Santos.

Koontz, H., y O'Donnell, C. (2006). Administration a global perspective. México: McGraw-Hill.

Korman, A. (1974). The Psychology of Motivation Englewood Cliffs. New Jersey: Prentice Hall.

Limonero, J.T., Tomás-Sábado, J., Fernández-Castro, J., y Gómez-Benito, J. (2004). Influence, Anxiety and Stress, 10(1), 29-41.

Mañas, M.A., Salvador, C., Boada, J., González, E., y Agulló, E. (2007). Satisfaction and psychological well-being as a background to organizational commitment. Psicothema, 19, 395-400.

Marrau, M.C. (2009). The burnout syndrome, in the contextualizing framework of work stress. Fundamentos en Humanidades, 10(19), 167-177.

Martínez-Selva, J.M. (2004). Work stress. Madrid: Pearson Educación.

Maslach, C. (1979). The Burnout Syndrome and Patients Care. In C. A. Garfield (Ed.), Stress and Survival: The Emotional Realities of Life-Threatening Illness (pp. 111-120). St Louis, MO: Mosby. Maslach, C. (1982). Burnout: The cost of caring. Nueva York: Prentice-Hall Press.

Maslach, C. y Jackson, S.E. (1981). MBI: Maslach Burnout Inventory Manual. Palo Alto: University of California, Consulting Psychologists Press. doi: 10.1037/t05190-000

Maslach, C. y Jackson, S.E. (1986). Maslach burnout inventory manual (2nd ed.). Palo Alto, CA: Consulting Psychologists Press.

Maslach, C., Jackson, S.E. y Leiter, M.P. (1996). Maslach Burnout Inventory Manual (3rd ed.). Mountain View, CA: CPP, Inc.

Maslach, C., y Leiter, M. (1999). Teacher burnout: A research agenda. In R. Vandenberg \& A. Huberman (Eds.), Understanding and Preventing Teacher Burnout (pp. 295-303). Cambridge: Cambridge University Press.

Meliá, J.L. y Peiró, J.M. (1989). The measurement of job satisfaction in organizational settings: The S20/23 Job Satisfaction Questionnaire. Psicologemas, 5, 59-74.

Nader, M., y Solano, A.C. (2010). Implicit theories of leadership, LMX and labor welfare: generalization of a theoretical model. Psicología, 28(2), 227-258.

Patlán, J. (2013). Effect of burnout and overload on the quality of life at work. Estudios Gerenciales, 29(129), 445-455. doi: 10.1016/j. estger.2013.11.010

Peiró, J.M. y Salvador, A. (1992). Triggers of Work Stress. España: Editorial UDEMA S. A.

Pérez, I. (2005). Work stress and burn-out syndrome, suffering and nonsense at work, strategies to face them. Buenos Aires: Psicoteca.

Pines, A., Aronson, E. y Kafry, D. (1981). Burn out: from tedium to personal growth. Nueva York: Free Press. 
Pines, A. y Aronson, E. (1988). Career Burnout: Causes and cures. New York: Free Press

Pines, A. y Krafy, D. (1978). Coping with burnout. Paper presented at the Annual Convention of the American Psychology Association. Toronto: Canada

Rodríguez, Y.E. y Reyes, M.R. (2010). Labor wellbeing and its impact on the successful management of companies in tourism. Turydes, 3(8), $1-12$.

Selye, H. (1950). Stress: The physiology and pathology of exposures to stress. Montreal: Acta Inc.
Siegrist, J. (1996). Adverse health effects of higheffort/low-reward conditions. Journal of Occupational Health Psychology, 1(1), 27-41. doi: 10.1037//1076-8998.1.1.27

Solana, R. (1993). Administration of Organizations. Buenos Aires: Interoceanic Editions S.A.

Trigo, T.R., Teng, C. y Hallak, J. (2007). Síndrome de burnout ou estafa profissional e os transtornos psiquiátricos. Revista de Psiquiatría Clínica, 34(5), 223-233. doi: 10.1590/s010160832007000500004

Received: October 11, 2017

Accepted: September 2, 2019 
